\title{
Vitamin D status in Greenland is influenced by diet and ethnicity: a population-based survey in an Arctic society in transition
}

\author{
Stig Andersen ${ }^{1,2 *}$, Peter Laurberg ${ }^{3}$, Bodil Hvingel ${ }^{4}$, Kent Kleinschmidt ${ }^{2}$, Lene Heickendorff ${ }^{5}$ and \\ Leif Mosekilde ${ }^{6}$ \\ ${ }^{1}$ Arctic Health Research Centre, Aalborg University Hospital, Hobrovej 42D, 9000 Aalborg, Denmark \\ ${ }^{2}$ Department of Medicine, Queen Ingrids Hospital, Nuuk, Greenland \\ ${ }^{3}$ Department of Endocrinology, Aalborg University Hospital, Aalborg, Denmark \\ ${ }^{4}$ Department of Surgery, Queen Ingrids Hospital, Nuuk, Greenland \\ ${ }^{5}$ Department of Clinical Biochemistry, Aarbus University Hospital, Aarbus, Denmark \\ ${ }^{6}$ Department of Endocrinology and Internal Medicine, Aarbus University Hospital, Aarhus, Denmark
}

(Submitted 11 January 2012 - Final revision received 18 April 2012 - Accepted 18 April 2012 - First published online 8 June 2012)

\begin{abstract}
Vitamin D status as measured by plasma 25-hydroxyvitamin D (25(OH)D) is important to human health. Circumpolar people rely on dietary sources and societal changes in the Arctic are having profound dietary effects. The objective of the present study was to determine plasma 25(OH)D status and factors important to plasma 25(OH)D in populations in Greenland. Inuit and non-Inuit aged 50-69 years in the capital in West Greenland (latitude $64^{\circ} 15^{\prime} \mathrm{N}$ ) and in a major town and remote settlements in East Greenland (latitude $65^{\circ} 35^{\prime} \mathrm{N}$ ) were surveyed. Supplement use and lifestyle factors were determined by questionnaires. Inuit food scores were computed from a FFQ of seven traditional Inuit and seven imported food items. $25(\mathrm{OH}) \mathrm{D}_{2}$ and $25(\mathrm{OH}) \mathrm{D}_{3}$ levels were measured in the plasma. We invited $1 \%$ of the population of Greenland, and $95 \%$ participated. $25(\mathrm{OH}) \mathrm{D}_{3}$ contributed $99 \cdot 7 \%$ of total plasma $25(\mathrm{OH}) \mathrm{D}$. Non-Inuit had the lowest median plasma $25(\mathrm{OH}) \mathrm{D}$ of 41 (25th-75th percentile $23-53) \mathrm{nmol} / \mathrm{l}$ compared with 64 (25th-75th percentile $51-81) \mathrm{nmol} / \mathrm{l}$ in Inuit $(P<0 \cdot 001)$. Plasma 25(OH)D was below 20 and $50 \mathrm{nmol} / 1$ in 13.8 and $60 \cdot 1 \%$ of participants, respectively, with Inuit food item scores below $40 \%(P<0.001)$, and in 0.2 and $25.0 \%$ of participants, respectively, with higher scores $(P<0 \cdot 001)$. The Inuit diet was an important determinant of plasma $25(\mathrm{OH}) \mathrm{D}(P<0 \cdot 001)$ and its effect was modified by ethnicity $(P=0 \cdot 005)$. Seal $(P=0 \cdot 005)$ and whale $(P=0 \cdot 015)$ were major contributors to plasma $25(\mathrm{OH}) \mathrm{D}$. In conclusion, a decrease in the intake of the traditional Inuit diet was associated with a decrease in plasma 25(OH)D levels, which may be influenced by ethnicity. The risk of plasma 25(OH)D deficiency in Arctic populations rises with the dietary transition of societies in Greenland. Vitamin D intake and plasma 25(OH)D status should be monitored.
\end{abstract}

\section{Key words: Plasma 25-hydroxyvitamin D: FFQ: Inuit Eskimos: Arctic Greenland: Lifestyle changes: Westernisation:} Population-based study

Vitamin D deficiency is associated with adverse health outcomes and increases the risk of osteoporosis, falls and fractures $^{(1-8)}$. Epidemiological evidence has linked low plasma 25-hydroxyvitamin D (25(OH)D) to a number of inflammatory, infectious, cardiovascular and metabolic disorders, and with cancers ${ }^{(9-19)}$. Thus, vitamin D is important for human health.

The endogenous production of $25(\mathrm{OH}) \mathrm{D}$ depends on the UVB-mediated conversion of 7-dehydrocholesterol to previtamin $\mathrm{D}_{3}$ and further isomerisation to vitamin $\mathrm{D}_{3}$ in the skin ${ }^{(10)}$. This depends on exposure to sunlight and plasma 25(OH)D levels in groups of Caucasian individuals decrease with increasing latitude ${ }^{(9,10,19,20)}$. Thus, low plasma levels of $25(\mathrm{OH}) \mathrm{D}$ are seen in, for example, Scandinavian populations ${ }^{(21,22)}$ even during the summer ${ }^{(19)}$. Very low levels of 25(OH)D may be found in Arctic populations characterised by low sun exposure and heavy outdoor clothing.

Diet provides yet another source of plasma 25(OH)D, with free-living fish and sea mammals being particularly rich in vitamin $\mathrm{D}^{(9,19,23,24)}$. These dominate the traditional Inuit (Eskimo) diet ${ }^{(19,25,26)}$ and the Inuit consider seal and whale blubber to be of particular dietary value. This may compensate

Abbreviation: 25(OH)D, 25-hydroxyvitamin D.

*Corresponding author: Dr S. Andersen, fax +45 99326108, email stiga@dadlnet.dk 
for the lack of exposure to the sun and thus of dermal vitamin

$\mathrm{D}$ production in Arctic residents.

Transition of Greenlandic societies started around 1960 and has occurred at different paces in different parts of Greenland $^{(27)}$, so that, today, settlements, towns and the capital city display different degrees of Westernisation ${ }^{(26,27)}$. This has influenced the use of the traditional Inuit diet, which has decreased ${ }^{(26,27)}$, and this in turn has the potential to influence plasma $25(\mathrm{OH}) \mathrm{D}^{(25)}$. Furthermore, obesity rates in Inuit have increased in parallel with transition ${ }^{(28)}$. This is associated with lower plasma $25(\mathrm{OH}) \mathrm{D}$ in other populations ${ }^{(10)}$ and may have a similar effect in Inuit.

This led us to study dietary habits and plasma 25(OH)D in cohorts living in the capital city Nuuk in West Greenland and in the rural Ammassalik district in East Greenland. We evaluated the impact of dietary components on plasma $25(\mathrm{OH}) \mathrm{D}$ in Arctic population groups. In addition, we assessed the influence of ethnicity on plasma 25(OH)D.

\section{Subjects and methods}

\section{Area of investigation}

Nuuk $\left(64^{\circ} 15^{\prime} \mathrm{N}, 51^{\circ} 35^{\prime} \mathrm{W}\right)$ in West Greenland is the capital city of Greenland with 13000 inhabitants of whom $75 \%$ are Inuit (Eskimo) and 25\% non-Inuit (Caucasians). Nuuk was established as a trading post under the Danish crown in 1728 and is now a modern city with access to a wide variety of food items including fast food, Italian food, Thai food and takeaways, supplementary to traditional Greenlandic food items. Furthermore, a wide variety of food items imported from Denmark is available in a number of stores.

The Ammassalik district $\left(65^{\circ} 35^{\prime} \mathrm{N}, 38^{\circ} 00^{\prime} \mathrm{W}\right)$ in East Greenland was isolated until 1884 and is still today difficult to access by sea due to pack ice from the northern ice cap. It is sparsely populated with 2943 inhabitants (93\% Inuit) spread over an area of $243000 \mathrm{~km}^{2}$. Tasiilaq is the main town of the Ammassalik district, which has seven settlements. Tasiilaq has one store with a limited food selection and five minor shops. Each of the settlements has one store with a limited selection depending on access by sea and air.

\section{Subjects and procedures}

Participants and procedures have been described in detail previously $^{(26)}$. We invited 50-69-year-old men and women, both Greenlanders (all Inuit) and non-Greenlanders (all Caucasian Danes), recorded and living at the address. The places selected for the investigation were Nuuk, Tasiilaq, and the settlements Tiniteqilaaq, Sermiligaaq, Kulusuk and Kuummiut in the Ammassalik district. Only the settlements with more than fifteen inhabitants in the selected age group were included. In Nuuk, names and addresses were obtained from the hospital registration system that keeps records of all inhabitants of Nuuk. A random sample of $25 \%$ of the total population aged 50-69 years was selected. The hospital registration system had not been regularly updated and for the investigation in Ammassalik, names and addresses were obtained from the National Civil Registration System in which every person living in Denmark, the Faeroe Islands and Greenland is registered. We invited 225 persons in Nuuk, 184 in Tasiilaq, nineteen in Tiniteqilaaq, twenty-eight in Sermiligaaq, fifty-two in Kulusuk, fifty-three in Kuummiut, and 95\% participated. A Greenlander (Inuit) was defined as an individual born in Greenland with both parents born in Greenland.

The present study was conducted according to the guidelines laid down in the Declaration of Helsinki and all procedures were approved by the Commission for Scientific Research in Greenland (reference no. 2010-8). All subjects gave informed written consent in Danish or Greenlandic by the participant's choice.

The local hospital porter or the nursing station attendant delivered a letter of invitation. The investigation took place at the local hospital or nursing station or by request as home visits. A physical examination was performed including height without shoes, weight in indoor clothing and recording of major disabilities. Participants were interviewed by a Greenlandic interpreter or by one of the investigating doctors (S. A., P. L. and B. H.), completing a questionnaire in either Danish or Greenlandic as appropriate for the participant. Information regarding age and sex was obtained from the National Civil Registration System. Information on lifestyle patterns and dietary habits was obtained by questionnaires. Questions were asked as written in the questionnaires. The same interpreter was used in Nuuk, Tasiilaq and all settlements.

\section{Dietary habits}

An interview-based FFQ was used to assess dietary habits. It included seven traditional Inuit (seal, whale, wild fowl, fish, reindeer, musk ox and hare) and seven imported food items (pre-cooked meals, potatoes, vegetables, butter, cheese, eggs and fresh fruit). These food items had been selected because they were typical to the diet in Greenland and they have been used previously ${ }^{(26)}$. For each food item, six different frequency categories were given from 'never' to 'daily intake'. A frequency score was calculated based on the average number of days per month the food item was ingested ${ }^{(26)}$. Inuit food items scored positively and imported food items scored negatively. The sum of frequency scores for all food items consumed by each participant was calculated and individuals were categorised as follows: diet group 1, >80\%; diet group 2, 60-80\%; diet group 3, 40-60\%; diet group 4, $20-40 \%$; diet group 5, $<20 \%$ Inuit food item scores on a scale where $100 \%$ was purely Inuit foods and $0 \%$ was purely imported food. We did not assess portion size for practical reasons but food-frequency scores were validated by cross-check questions as well as by a biomarker of the intake of traditional Inuit foods ${ }^{(26)}$.

The intake of vitamin D-containing supplements was evaluated by asking the frequency of intake. Supplements were presented to one of the investigating doctors for evaluation. Contents and type of vitamin D differed between supplements available. Vitamin D content was evaluated based on the 
interview if no supplement was presented. Subjects were classified by daily intakes (yes/no).

\section{Plasma 25-hydroxyvitamin D assay}

Plasma 25(OH)D levels were analysed by isotope dilution liquid chromatography-tandem MS (LC-MS/MS) as described earlier ${ }^{(29)}$. Calibrators traceable to a NIST standard reference material (SRM972) were used (ChromSystems).

\section{Statistics}

Results are presented as medians with 25 th and 75 th percentiles. The plasma 25(OH)D groups were compared using non-parametric statistics: Mann-Whitney $U$ test for comparison of two groups; Kruskal-Wallis test for comparing several groups; Kendall's $\tau$ for the relationship between the groups. Plasma 25(OH)D followed the normal distribution $(P=0 \cdot 17)$, and linear regression models were used with plasma $25(\mathrm{OH}) \mathrm{D}$ as the dependent variable. Interaction was tested in multivariate logistic regression analysis. Explanatory variables were diet group, participant group, ethnic origin, use of supplements, BMI, age, sex and alcohol intake (average number of units per week). Diet, participant group and origin were investigated individually in the multivariate linear regression analysis due to covariance between these. Random selection of participants in Nuuk was performed using MedStat (Astra). Data were processed and analysed using Corel Quattro Pro 8 (Corel Corporation) and the Statistical Package for the Social Sciences version 13.0 (SPSS, Inc.). A $P$ value of less than 0.05 was considered significant.

\section{Results}

For the present study, $1 \%$ of the population of Greenland was invited and the participation rate was $95 \%$. The characteristics of the participants are given in Table 1 . In the case of nonInuit, seven had one parent born in Greenland while ninetyfour had neither parent born in Greenland. Non-Inuit were more frequent users of vitamin preparations than Inuit (Table 1). Non-Inuit were skilled labour from Denmark and included more men than women $(P<0 \cdot 001)$. Also, there

Table 1. Descriptive information on participants in the diet and vitamin D survey in East and West Greenland

(Number of participants and percentages)

\begin{tabular}{|c|c|c|c|c|c|c|c|c|c|c|}
\hline & \multicolumn{2}{|c|}{ Non-Inuit* } & \multicolumn{2}{|c|}{ Inuit in Nuuk } & \multicolumn{2}{|c|}{$\begin{array}{l}\text { Inuit in } \\
\text { Tasiilaq }\end{array}$} & \multicolumn{2}{|c|}{$\begin{array}{c}\text { Inuit in } \\
\text { settlements }\end{array}$} & \multirow[b]{2}{*}{$P \dagger$} & \multirow[b]{2}{*}{$P \ddagger$} \\
\hline & $n$ & $\%$ & $n$ & $\%$ & $n$ & $\%$ & $n$ & $\%$ & & \\
\hline \multicolumn{11}{|l|}{ Number of participants } \\
\hline All & 101 & 100 & 150 & 100 & 141 & 100 & 143 & 100 & & \\
\hline Taking vitamin D-containing supplements & 22 & $21 \cdot 8$ & 15 & $10 \cdot 0$ & 5 & 3.5 & 3 & $2 \cdot 1$ & $<0.001$ & 0.004 \\
\hline \multicolumn{11}{|l|}{ Sex } \\
\hline Men & 80 & $79 \cdot 2$ & 70 & $46 \cdot 7$ & 80 & $56 \cdot 7$ & 79 & $55 \cdot 2$ & $<0.001$ & $0 \cdot 17$ \\
\hline Women & 21 & $20 \cdot 8$ & 80 & $53 \cdot 3$ & 61 & $43 \cdot 3$ & 64 & 44.8 & & \\
\hline \multicolumn{11}{|l|}{ Taking vitamin D-containing supplements } \\
\hline Men & 15 & 14.9 & 6 & 4.0 & 3 & $2 \cdot 1$ & 1 & 0.7 & 0.70 & 0.49 \\
\hline Women & 7 & 6.9 & 9 & $6 \cdot 0$ & 2 & 1.4 & 2 & 1.4 & & \\
\hline \multicolumn{11}{|l|}{ Age (years) } \\
\hline $50-59$ & 85 & $84 \cdot 2$ & 87 & $58 \cdot 0$ & 87 & $61 \cdot 7$ & 85 & $59 \cdot 4$ & & \\
\hline $60-69$ & 16 & $15 \cdot 8$ & 63 & $42 \cdot 0$ & 54 & $38 \cdot 3$ & 58 & $40 \cdot 6$ & $<0.001$ & 0.81 \\
\hline \multicolumn{11}{|l|}{ BMI $\left(\mathrm{kg} / \mathrm{m}^{2}\right)$} \\
\hline \multicolumn{11}{|l|}{ Men§ } \\
\hline$<30$ & 65 & $81 \cdot 3$ & 45 & 78.9 & 69 & $87 \cdot 3$ & 72 & $91 \cdot 1$ & $0 \cdot 16$ & 0.12 \\
\hline $30+$ & 15 & $18 \cdot 7$ & 12 & $21 \cdot 1$ & 10 & $12 \cdot 7$ & 7 & 8.9 & & \\
\hline \multicolumn{11}{|l|}{ Women§ } \\
\hline$<30$ & 19 & $90 \cdot 5$ & 51 & $76 \cdot 1$ & 46 & $78 \cdot 0$ & 48 & $76 \cdot 2$ & 0.54 & 0.96 \\
\hline $30+$ & 2 & 9.5 & 16 & $23 \cdot 9$ & 13 & $22 \cdot 0$ & 15 & $23 \cdot 8$ & & \\
\hline \multicolumn{11}{|l|}{ Smoker\| } \\
\hline Present & 57 & $56 \cdot 5$ & 111 & 74.0 & 108 & $76 \cdot 6$ & 109 & $76 \cdot 2$ & & \\
\hline Past & 18 & $17 \cdot 8$ & 16 & $10 \cdot 7$ & 14 & 9.9 & 19 & $13 \cdot 3$ & & \\
\hline Never & 26 & $25 \cdot 7$ & 22 & $14 \cdot 7$ & 19 & 13.5 & 15 & $10 \cdot 5$ & 0.008 & 0.75 \\
\hline \multicolumn{11}{|l|}{ Alcohol use (units) } \\
\hline$<7$ & 56 & 55.4 & 92 & $61 \cdot 3$ & 88 & $62 \cdot 4$ & 94 & $65 \cdot 7$ & & \\
\hline $7-21$ & 32 & 31.7 & 50 & $33 \cdot 3$ & 46 & $32 \cdot 6$ & 37 & $25 \cdot 9$ & & \\
\hline$>21$ & 12 & 11.9 & 2 & $1 \cdot 3$ & 5 & 3.5 & 12 & 8.4 & $<0.001$ & $<0.001$ \\
\hline \multicolumn{11}{|l|}{ Hunting ${ }^{\star \star}$} \\
\hline Trade & 2 & $2 \cdot 0$ & 8 & $5 \cdot 3$ & 22 & $15 \cdot 6$ & 45 & 31.5 & & \\
\hline Leisure & 39 & 38.6 & 44 & $29 \cdot 3$ & 52 & $36 \cdot 9$ & 53 & $37 \cdot 0$ & & \\
\hline Rarely & 60 & 59.4 & 93 & $62 \cdot 0$ & 65 & $46 \cdot 1$ & 45 & 31.5 & $<0.001$ & $<0.001$ \\
\hline
\end{tabular}

* Including seven participants of mixed origin.

$+\chi^{2}$ test for comparing proportions among all groups.

$\ddagger \chi^{2}$ test for comparing proportions among Inuit.

$\S \mathrm{BMI}$ increased from settlement to town to city in Inuit men (trend, $P=0.010$ ) but not in women (trend, $P=0.39$ ).

|| Information missing for one participant.

I Estimated units of alcohol per week. Information missing for nine participants.

** Information missing for seven participants. 
were fewer non-Inuit than Inuit in the age group of 60-69 years and the mean age was lower (men $P=0.001$, women $P=0.005$; Table 1) because some leave Greenland when retiring. The study cohorts represented different levels of Westernisation as illustrated by hunting habits (Table 1). The two participants categorised as non-Inuit who reported hunting as a trade were of mixed origin.

\section{Dietary habits}

Dietary habits differed between the participant groups (Fig. 1). Of the participants, $93 \%$ of Inuit in settlements had a food-frequency score of more than $60 \%$ traditional foods compared with $86 \%$ of Inuit in Tasiilaq, $59 \%$ of Inuit in Nuuk and 3\% of non-Inuit. Conversely, $83 \%$ of non-Inuit reported a foodfrequency score of more than $60 \%$ imported foods, while this was $14 \%$ of Inuit in Nuuk and $1.4 \%$ of Inuit in both Tasiilaq and settlements. Differences in dietary habits were marked between Inuit and non-Inuit $(P<0.001)$ as well as between the Inuit groups $(P<0 \cdot 001)$. No seasonal differences in Inuit food frequency were reported.

\section{Vitamin D}

Plasma $25(\mathrm{OH}) \mathrm{D}_{3}$ contributed $62.30 \mathrm{nmol} / 1(99 \cdot 7 \%)$ to the overall mean of $62.50 \mathrm{nmol} / 1$ of total $25(\mathrm{OH}) \mathrm{D}$ in the plasma, while $25(\mathrm{OH}) \mathrm{D}_{2}$ contributed only $0 \cdot 3 \%$. This proportion was $0 \cdot 2 \%$ in Inuit and $1.4 \%$ in non-Inuit not taking vitamin D-containing supplements $(P=0 \cdot 005)$.

\section{Diet and vitamin D}

Fig. 2 shows that there was a significant $(P<0 \cdot 001)$ difference in plasma $25(\mathrm{OH}) \mathrm{D}$ levels between the participants in the five

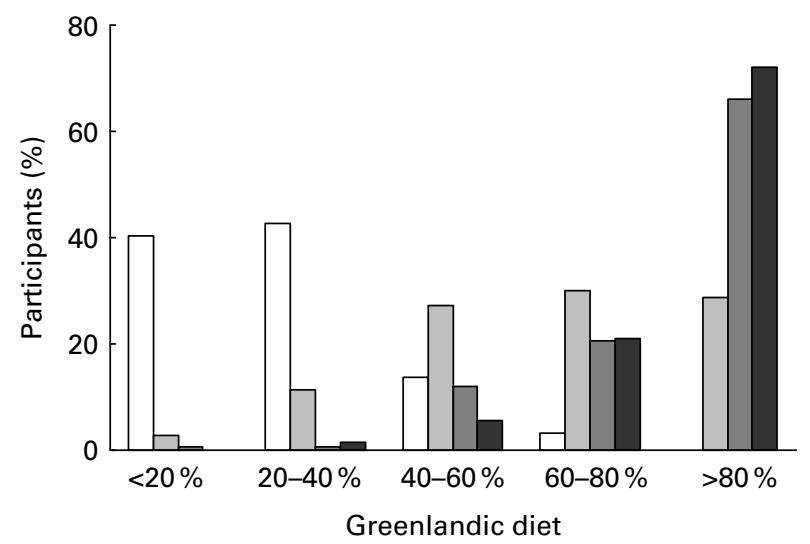

Fig. 1. Food-frequency scores among the population groups in the capital city Nuuk (latitude $64^{\circ} 15^{\prime} \mathrm{N}$ ) in West Greenland and in the Ammassalik district (latitude $65^{\circ} 35^{\prime} \mathrm{N}$ ) in rural East Greenland. Classification was based on frequencies of intake of seven traditional Inuit (seal, whale, wild fowl, fish, reindeer, musk ox and hare) and seven imported food items (pre-cooked meals, potatoes, vegetables, butter, cheese, eggs and fresh fruit). Six different frequency categories were given for each food item from 'never' to 'daily intake' and a frequency score was calculated. Individuals were categorised based on frequency scores on a scale where $100 \%$ is purely Inuit foods and $0 \%$ is purely imported foods. $\square$, Non-Inuit; $\square$, Inuit in city; $\square$, Inuit in town; $\square$, Inuit in settlement.

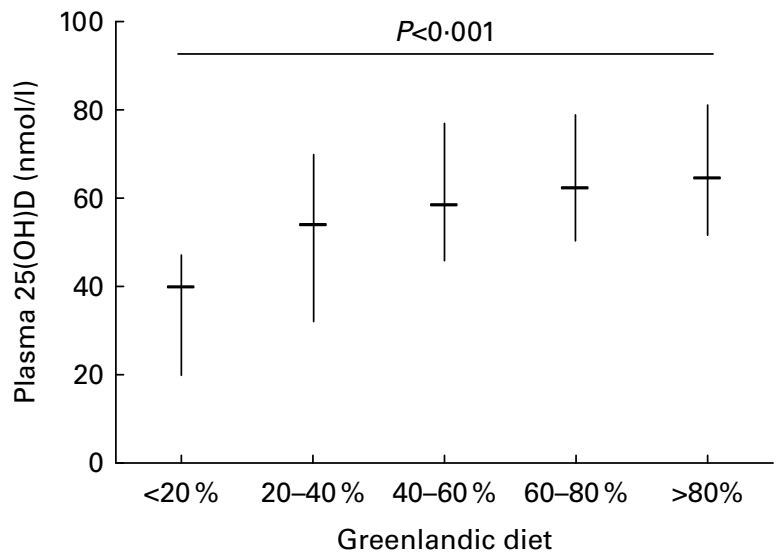

Fig. 2. Plasma 25-hydroxyvitamin $\mathrm{D}(25(\mathrm{OH}) \mathrm{D})$ in each food-frequency group where $100 \%$ is purely Inuit foods and $0 \%$ is purely imported foods. Values are medians, with 25 th and 75 th percentiles represented by vertical bars.

diet groups. A diet based on mainly imported foods was associated with a mean total plasma 25(OH)D level of $36 \mathrm{nmol} / 1$. This increased gradually $(P<0 \cdot 001)$ to $68 \mathrm{nmol} / 1$ in the group with a diet comprising mainly traditional Inuit food items. The dietary components reported by Inuit that contributed markedly to plasma $25(\mathrm{OH}) \mathrm{D}$ were seal $(P=0 \cdot 005)$ and whale $(P=0 \cdot 015)$.

The occurrence of plasma 25(OH)D below $50 \mathrm{nmol} / 1$ decreased with a higher intake of Inuit foods (Fig. 3) and $25(\mathrm{OH}) \mathrm{D}$ below $20 \mathrm{nmol} / \mathrm{l}$ was seen only in those with a low intake of traditional Inuit foods.

\section{Ethnicity and vitamin D}

Inuit had a higher plasma $25(\mathrm{OH}) \mathrm{D}$ than non-Inuit (Fig. 4). They also had the highest intake of traditional Inuit foods (Fig. 1). Table 2 lists the factors important to plasma 25(OH)D levels. Diet, lifestyle and ethnicity influenced plasma $25(\mathrm{OH}) \mathrm{D}$ in the adjusted analysis. A plasma 25(OH)D level below $50 \mathrm{nmol} / 1$ was more likely with Inuit food scores below $60 \%(P<0.001$; OR 5.4, $95 \%$ CI 3.3, 8.8) and was modified by ethnicity (ethnicity $\times$ diet as an interaction term, $P=0.005)$ in the multivariate logistic regression analysis.

\section{Discussion}

This is the first population-based study of the relationship between plasma $25(\mathrm{OH}) \mathrm{D}$ and the transition of societies in Greenland. We found that decreasing intake of the traditional Inuit diet was followed by a decrease in $25(\mathrm{OH}) \mathrm{D}$ in the plasma and an emerging vitamin D deficiency. Furthermore, seal and whale were major contributors to plasma 25(OH)D in populations in Greenland. Interestingly, ethnicity may influence the impact of dietary habits on plasma 25(OH)D.

Vitamin D synthesis in humans requires UVB exposure of the skin. In Caucasians, low UVB exposure in high-latitude countries is associated with an increased risk of low plasma $25(\mathrm{OH}) \mathrm{D}^{(1,9,10,19-21)}$. Greenland hosts the most northern 


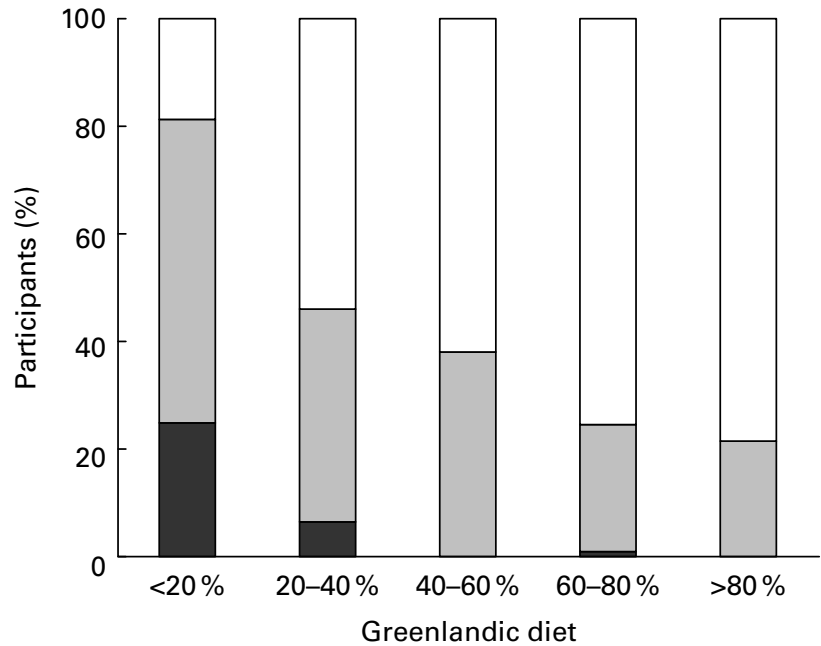

Fig. 3. Fraction of participants with plasma 25-hydroxyvitamin $D$ below $20 \mathrm{nmol} / \mathrm{l}(\square)$, between 20 and $50 \mathrm{nmol} / \mathrm{l}(\square)$ and above $50 \mathrm{nmol} / /(\square)$ for each food-frequency group where $100 \%$ is purely Inuit foods and $0 \%$ is purely imported foods.

habitats on Earth with a high solar zenith angle and consequently a very low intensity of UVB as the radiation is absorbed through its oblique passage through the atmosphere. Also, Greenland is an Arctic environment defined by the mean temperature being below $10^{\circ} \mathrm{C}$ during the warmest month. This influences clothing habits also during summer. Hence, very limited dermal production of vitamin $D$ is expected in populations in Greenland and dietary sources are crucial to maintain adequate plasma 25(OH)D levels ${ }^{(25,30-32)}$.

Vitamin D plays a pivotal role in skeletal health and low levels are associated with rickets, osteomalacia and osteoporosis with an increased risk of fractures ${ }^{(1,4-8,10)}$. Vitamin D may also be important for the functioning of other systems, such as the immune system ${ }^{(10,33)}$. As for the latter, tuberculosis is frequent in Greenland but is associated with both low and high plasma $25(\mathrm{OH}) \mathrm{D}^{(34)}$. As for the former, knowledge of Inuit skeletal health is limited. Bone mineral density did not differ between Inuit and non-Inuit in North Greenland ${ }^{(35)}$. On the other hand, more frequent hip fractures were reported in Alaska compared with southern states in the USA ${ }^{(36)}$. However, that study did not take into consideration differences in hours of sunlight and icy pavements. Still, plasma $25(\mathrm{OH}) \mathrm{D}$ is associated with the risk of falls ${ }^{(2,3)}$ and myopathy ${ }^{(1,37,38)}$, even though reports on falls in Greenland are lacking, and a sufficient plasma $25(\mathrm{OH}) \mathrm{D}$ status is important to human health $^{(1,10,39)}$.

Vitamin D is ample in traditional Inuit foods that comprise mainly marine mammals and fish, with blubber from seal and whale considered to be of particular value, in addition to caribou and birds ${ }^{(30)}$. Hence, dietary assessment interviews in a large group of Canadian Inuit have reported an intake of vitamin $\mathrm{D}$ exceeding the recommended adequate intake by up to $100 \%{ }^{(25)}$. It has also been reported that days with meals of traditional Inuit foods provided $25 \mu \mathrm{g}$ vitamin $\mathrm{D}^{(30)}$.
In contrast, dietary record studies have reported low intakes of vitamin $\mathrm{D}$ in the majority of Canadian Inuit in Nunavut and Northwest Territories ${ }^{(19,40-43)}$. A contributor to this discrepancy could be dietary transition as the intake of traditional Inuit foods is lower in younger compared with older individuals $^{(30,44)}$. This was supported by plasma $25(\mathrm{OH}) \mathrm{D}$ in Greenland Inuit in Nuuk and Denmark classified by a weekly intake of marine mammals (yes/no) ${ }^{(45)}$.

We performed a detailed classification of the diet by including non-Inuit and Inuit living in both an urban area with ample market foods and rural areas with limited availability of these and dependency on hunting and fishing. Participants were categorised based on the frequency of intake of traditional Inuit and imported market foods. This method is limited to the frequency of intake of food items used for main meals and does not include, for example, cereal foods. Also, we did not assess portion size. This hampers the accuracy of our estimates of food intakes but an equal influence on imported and traditional Inuit foods may be anticipated and hence a limited influence on the extent to which groups of subjects were categorised as traditional Inuit or Westernised eaters. Also, the method has been validated for description of the degree of adherence to the traditional Inuit diet ${ }^{(26)}$. The diet groups were associated markedly with plasma $25(\mathrm{OH}) \mathrm{D}$ and we found $88 \%$ higher plasma $25(\mathrm{OH}) \mathrm{D}$ values in the group with the highest compared with the lowest intake of traditional Inuit foods. This is twice the difference found in the study with a more crude classification of the $\operatorname{diet}^{(45)}$ but in keeping with the findings among Canadian Inuit $^{(30-32)}$. Still, plasma $25(\mathrm{OH}) \mathrm{D}$ was $68 \mathrm{nmol} / 1$ in the group with the highest intake of traditional Inuit foods and thus not exceedingly high.

We found plasma $25(\mathrm{OH}) \mathrm{D}$ deficiency, defined as plasma $25(\mathrm{OH}) \mathrm{D}<50 \mathrm{nmol} / \mathrm{l}$, in one in four subjects in the group with an Inuit diet score below $20 \%$. This was absent when the diet score was above $40 \%$. These diet scores correspond to less than weekly intake of Greenlandic food items and an

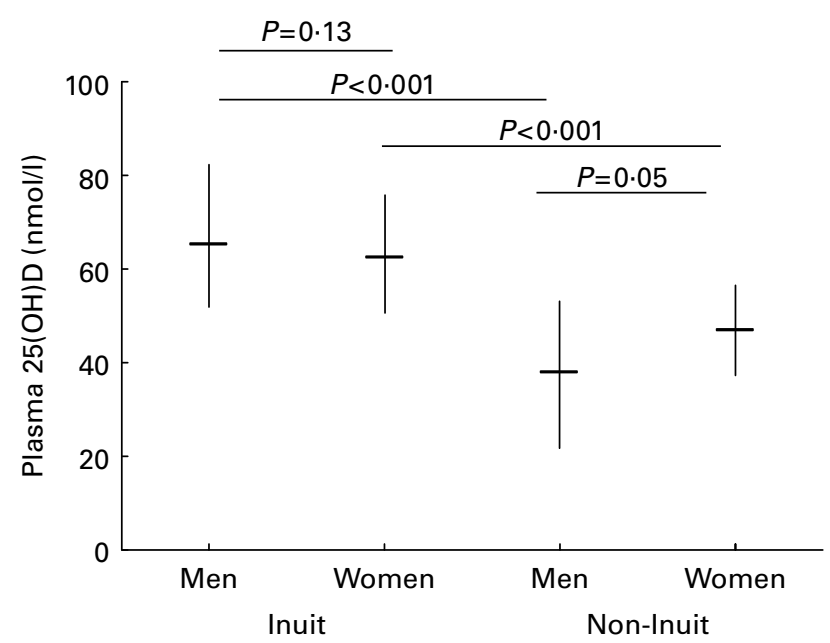

Fig. 4. Plasma 25-hydroxyvitamin $D(25(\mathrm{OH}) \mathrm{D})$ in Inuit and non-Inuit (Caucasian) men and women living in the capital city Nuuk in West Greenland and in the rural Ammassalik district in East Greenland. 
Table 2. Factors important to plasma 25-hydroxyvitamin D (25(OH)D) in residents in Greenland

( $\beta$ Coefficients and $P$ values)

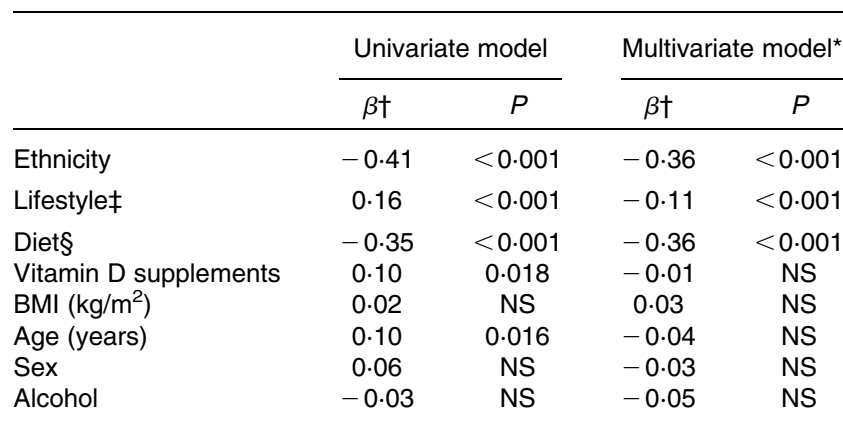

* Dependent variable was serum 25(OH)D and explanatory variables were weight, age, sex, alcohol intake, and either ethnicity, lifestyle or diet.

† $\beta$ (Regression) coefficients were as follows: Inuit/non-Inuit; city/town/settlements decreasing traditional Inuit diet; vitamin $\mathrm{D}$ supplement use $-/+$; increasing $\mathrm{BMI}$; increasing age; men/women; increasing alcohol intake.

$\ddagger$ Lifestyle represented by participant groups at different levels of Westernisation: non-Inuit; Inuit in city; Inuit in town; Inuit in settlement (as in Table 1).

$\S$ Diet based on the diet groups calculated from the frequency of intake of seven Inuit and seven imported food items: diet group 1, >80\%; diet group 2, 60$80 \%$; diet group 3, 40-60\%; diet group 4, 20-40\%; diet group 5, 0-20\% Inuit food-frequency scores.

intake three times weekly or more, respectively. The group with an intake of traditional Inuit foods less than weekly had a $25(\mathrm{OH}) \mathrm{D}$ level that matched the finding in Nuuk using the more simple dietary classification ${ }^{(45)}$. The validity of this crude classification was supported by the present finding of seal and whale as the two major food items in the Inuit diet that were important for plasma $25(\mathrm{OH}) \mathrm{D}$. However, such crude classification could not detect a difference in plasma $25(\mathrm{OH}) \mathrm{D}$ in a more recent study ${ }^{(34)}$. Thus, our more detailed classification of the traditional Inuit diet contributed to a more comprehensive description of the association between the traditional Inuit diet and plasma $25(\mathrm{OH}) \mathrm{D}$, which is supported by the findings in Canadian Inuit ${ }^{(30)}$.

We also found a higher plasma $25(\mathrm{OH}) \mathrm{D}$ in Inuit, who have darker skin compared with non-Inuit ${ }^{(43)}$. This is in keeping with the diet being the source of plasma $25(\mathrm{OH}) \mathrm{D}$ as whites tend to have higher $25(\mathrm{OH}) \mathrm{D}$ than do those with darker skin at lower latitudes, i.e. in the $\mathrm{USA}^{(46)}$, the $\mathrm{UK}^{(47)}$ and immigrants to Scandinavia ${ }^{(48)}$. The study by Rejnmark et al. ${ }^{(45)}$ found lower plasma $25(\mathrm{OH}) \mathrm{D}$ among Inuit than among nonInuit in Denmark. This may relate to skin pigmentation but further ethnic differences are supported by the present finding that ethnicity modified the influence of diet on plasma $25(\mathrm{OH}) \mathrm{D}$. Our indirect measure of the influence of ethnicity was distinct $(P=0.005)$ but should be confirmed in direct comparisons. Whether the difference relates to the bioavailability or metabolism of plasma $25(\mathrm{OH}) \mathrm{D}$ remains to be settled.

The capital city Nuuk hosts more obese subjects than does the town and settlements in East Greenland ${ }^{(28)}$. This could contribute to differences in plasma 25(OH)D levels as obesity reduces plasma $25(\mathrm{OH}) \mathrm{D}$ levels in other populations ${ }^{(10,49)}$. However, plasma 25(OH)D levels did not associate with BMI or weight in Inuit.

There was an association between the intake of traditional Inuit food items, the differences in the way of living between the study areas, the availability of imported food items, the frequency of fishing and hunting, and the fraction of non-Inuit. This limited the use of linear regression, but similar results were obtained using logistic regression, though this was less sensitive.

We studied only subjects aged 50-69 years. This might underestimate the impact of the transition away from traditional foods as older people eat more traditional foods ${ }^{(30,44)}$. Still, the older age group contributed to a high participation rate of $95 \%$, which supports the validity of the findings in the present population-based survey. Furthermore, the study included populations at the extremes of transition of societies in Greenland from the capital city Nuuk in West Greenland to remote settlements in East Greenland. Data on plasma $25(\mathrm{OH}) \mathrm{D}$ among populations in other areas of the more heavily populated west coast of Greenland are relevant as differences may apply in diet, lifestyle and genetics. Also, follow-up on the populations included here is recommended both to examine the effect of low plasma $25(\mathrm{OH}) \mathrm{D}$ in Inuit, and to follow up on the impact of future transition in dietary habits. Finally, younger people have a lower intake of traditional Inuit food items with a higher risk of $25(\mathrm{OH}) \mathrm{D}$ deficiency ${ }^{(30,44)}$. Thus, younger groups should be included in future studies of vitamin D intake and plasma $25(\mathrm{OH}) \mathrm{D}$ in Greenland.

In conclusion, we found low plasma $25(\mathrm{OH}) \mathrm{D}$ in older people in Greenland who had a low intake of Inuit food items. This observation was associated with the transition of societies in Greenland in keeping with the findings in indigenous populations in the Canadian Arctic. Furthermore, the present study suggests that ethnicity may contribute to differences in plasma $25(\mathrm{OH}) \mathrm{D}$.

\section{Acknowledgements}

We gratefully acknowledge Karoline Berglund for her enthusiasm and thorough interviewing of Inuit. We are grateful for invaluable support from lægeklinikken in Nuuk, from Hans Chr. Florian Sørensen and the staff at the hospital in Tasiilaq, and from the staff at the nursing stations in Tiniteqilaaq, Sermiligaaq, Kuummiut and Kulusuk. This study was supported by grants from the following: Greenland Home Government; Karen Elise Jensen Foundation; Northern Jutland Research Foundation; Aalborg City Christmas Lottery; Danish Hospital Foundation for Medical Research, Region of Copenhagen, the Faeroe Islands and Greenland. The authors' contributions are as follows: S. A. contributed to the project conception, study design, raising of funds, data collection, analysis of the data and writing of the manuscript; P. L. participated in the project conception, study design, raising of funds, data collection, analysis of the data and reviewing of the manuscript; B. H. was responsible for the data collection and reviewing of the manuscript; K. K. participated in the study design and reviewing of the manuscript; L. H. was responsible for the analysis of the data, reviewing of the manuscript; L. M. contributed to the conception of the idea and writing of the manuscript. The authors declare that there are no conflicts of interest. 


\section{References}

1. Mosekilde L (2005) Vitamin D and the elderly. Clin Endocrinol 62, 265-281.

2. Bischoff-Ferrari HA, Dawson-Hughes B, Willett WC, et al. (2004) Effect of vitamin D on falls: a meta-analysis. JAMA 291, 1999-2006.

3. Larsen ER, Mosekilde L \& Foldspang A (2005) Vitamin D and calcium supplementation prevents severe falls in elderly community-dwelling women: a pragmatic populationbased 3-year intervention study. Aging Clin Exp Res 17, 125-132.

4. Bischoff-Ferrari HA, Willett WC, Wong JB, et al. (2009) Prevention of nonvertebral fractures with oral vitamin $\mathrm{D}$ and dose dependency: a meta-analysis of randomized controlled trials. Arch Intern Med 169, 551-561.

5. Chapuy MC, Arlot ME, Duboeuf F, et al. (1992) Vitamin $\mathrm{D}_{3}$ and calcium to prevent hip fractures in the elderly women. N Engl J Med 327, 1637-1642.

6. Chapuy MC, Arlot ME, Delmas PD, et al. (1994) Effect of calcium and cholecalciferol treatment for three years on hip fractures in elderly women. BMJ 308, 1081-1082.

7. Larsen ER, Mosekilde L \& Foldspang A (2004) Vitamin D and calcium supplementation prevents osteoporotic fractures in elderly community dwelling residents: a pragmatic population-based 3-year intervention study. I Bone Miner Res 19, 370-378.

8. DIPART group. (2010) Patient level pooled analysis of 68500 patients from seven major vitamin D fracture trials in US and Europe. (2010) BMJ 340, b5463.

9. Holick MF (2007) Vitamin D deficiency. $N$ Engl J Med 357, 266-281

10. Adams JS \& Hewison M (2010) Update in vitamin D. J Clin Endocrinol Metab 95, 471-478.

11. Jahnsen J, Falch JA, Mowinckel ZP, et al. (2002) Vitamin D status, parathyroid hormone and bone mineral density in patients with inflammatory bowel disease. Scand J Gastroenterol 37, 192-197.

12. Cutolo M, Plebani M, Shoenfeld Y, et al. (2011) Vitamin D endocrine systems and the immune response in rheumatic diseases. Vitam Horm 86, 327-351.

13. Van der Mei IA, Ponsonby AL, Dwyer T, et al. (2003) Past exposure to sun, skin phenotype, and risk of multiple sclerosis: case-control study. BMJ 327, 316.

14. Pfeifer M, Begerow B, Minne HW, et al. (2001) Effects of a short-term vitamin $\mathrm{D}(3)$ and calcium supplementation on blood pressure and parathyroid hormone levels in elderly women. J Clin Endocrinol Metab 86, 1633-1637.

15. Zittermann A, Schleithoff SS \& Koerfer R (2005) Putting cardiovascular disease and vitamin D insufficiency into perspective. Br J Nutr 94, 483-492.

16. Ma Y, Zhang P, Wang F, et al. (2011) Association between vitamin D and risk of colorectal cancer: a systematic review of prospective studies. J Clin Oncol 29, 3775-3782.

17. Gissel T, Rejnmark L, Mosekilde L, et al. (2008) Intake of vitamin D and risk of breast cancer - a meta analysis. J Steroid Biochem Mol Biol 111, 195-199.

18. Bell DS (2011) Protean manifestations of vitamin D deficiency, part 2: deficiency and its association with autoimmune disease, cancer, infection, asthma, dermopathies, insulin resistance, and type 2 diabetes. South Med J 104, $335-339$

19. Sharma S, Barr AB, Macdonald HM, et al. (2011) Vitamin D deficiency and disease risk among aboriginal Arctic populations. Nutr Rev 69, 468-478.
20. Hagenau T, Vest R, Gissel TN, et al. (2009) Global vitamin D levels in relation to age, gender, skin pigmentation and latitude: an ecologic meta-regression analysis. Osteoporos Int 20, 133-140.

21. Brot C, Vestergaard P, Kolthoff N, et al. (2001) Vitamin D status and its adequacy in healthy Danish perimenopausal women: relationships to dietary intake, sun exposure and serum parathyroid hormone. Br J Nutr 86, 97-s103.

22. Dalgård C, Petersen MS, Schmedes AV, et al. (2010) High latitude and marine diet: vitamin D status in elderly Faroese. $\mathrm{Br}$ J Nutr 104, 914-918.

23. Kleiver KM, Draper HH \& Ronald KJ (1988) Vitamin D metabolism in the hooded seal (Cystophora cristata). J Nutr 118, 332-341.

24. Lu Z, Chen TC, Zhang A, et al. (2007) An evaluation of the vitamin $D_{3}$ content in fish: is the vitamin $D$ content adequate to satisfy the dietary requirement for vitamin D? J Steroid Biochem Mol Biol 103, 642-644.

25. Kuhlein HV, Receveur O, Soueida R, et al. (2008) Unique patterns of dietary adequacy in three cultures of Canadian Arctic indigenous peoples. Publ Health Nutr 11, 349-360.

26. Andersen S, Hvingel B, Kleinschmidt K, et al. (2005) Changes in iodine excretion in 50-69-y-old denizens of an Arctic society in transition and iodine excretion as a biomarker of the frequency of consumption of traditional Inuit foods. Am J Clin Nutr 81, 656-663.

27. Bjerregaard P \& Young TK (1998) The Circumpolar Inuit Health of a Population in Transition. Copenhagen: Munksgaard.

28. Andersen S, Mulvad G, Pedersen HS, et al. (2004) Gender diversity in developing overweight over 35 years of westernization in an Inuit hunter cohort and ethno-specific body mass index for evaluation of body-weight abnormalities. Eur J Endocrinol 151, 735-740.

29. Hojskov CS, Heickendorff L \& Moller HJ (2010) Highthroughput liquid-liquid extraction and LCMSMS assay for determination of circulating $25(\mathrm{OH})$ vitamin $\mathrm{D}_{3}$ and $\mathrm{D}_{2}$ in the routine clinical laboratory. Clin Chim Acta 411, 114-116.

30. Kuhnlein HV \& Receveur O (2007) Local cultural animal food contributes high levels of nutrients for Arctic Canadian indigenous adults and children. J Nutr 137, 1110-1114.

31. Johnson-Down L \& Egeland GM (2010) Adequate nutrient intakes are associated with traditional food consumption in Nunavut Inuit children aged 3-5 years. J Nutr 140, $1311-1316$

32. Egeland GM, Johnson-Down L, Cao ZR, et al. (2011) Food insecurity and nutrition transition combine to affect nutrient intakes in Canadian arctic communities. J Nutr 141, $1746-1753$.

33. Bikle DD (2011) Vitamin D regulation of immune function. Vitam Horm 86, 1-21.

34. Nielsen NO, Skifte T, Andersson M, et al. (2010) Both high and low serum vitamin $\mathrm{D}$ concentrations are associated with tuberculosis: a case-control study in Greenland. $\mathrm{Br} \mathrm{J}$ Nutr 104, 1487-1491.

35. Andersen S, Boeskov E \& Laurberg P (2005) Ethnic differences in bone mineral density between Inuit and Caucasians in North Greenland are caused by differences in body size. $J$ Clin Densitom 8, 409-414.

36. Pratt WB \& Holloway JM (2001) Incidence of hip fracture in Alaska Inuit people: 1979-89 and 1996-99. Alaska Med 43, $2-5$.

37. Pfeifer M, Begerow B, Minne HW, et al. (2009) Effects of a long-term vitamin D and calcium supplementation on falls 
and parameters of muscle function in community-dwelling older individuals. Osteoporos Int 20, 315-322.

38. Glerup H, Mikkelsen K, Poulsen L, et al. (2000) Hypovitaminosis D myopathy without biochemical signs of osteomalacic bone involvement. Calcif Tissue Int 66, 419-424.

39. Autier P \& Gandini S (2007) Vitamin D supplementation and total mortality: a meta-analysis of randomized controlled trials. Arch Int Med 167, 1730-1737.

40. Sharma S, Cao X, Roache C, et al. (2010) Assessing dietary intake in a population undergoing a rapid transition in diet and lifestyle: the Arctic Inuit in Nunavut, Canada. Br J Nutr 103, 749-759.

41. Erber E, Hopping BN, Beck L, et al. (2010) Assessment of dietary adequacy in a remote Inuvialuit population. $J$ Hum Nutr Diet 23, 35-42.

42. El Hayek J, Egeland G \& Weiler H (2010) Vitamin D status of Inuit preschoolers reflects season and vitamin D intake. J Nutr 140, 1839-1845.

43. Frost P (2012) Vitamin D deficiency among northern Native Peoples: a real or apparent problem? Int J Circumpolar Health 71, 18001.
44. Kuhnlein HV, Receveur O, Soueida R, et al. (2004) Arctic indigenous peoples experience the nutrition transition with changing dietary patterns and obesity. $J$ Nutr $\mathbf{1 2 4}$, 1447-1453.

45. Rejnmark L, Jørgensen ME, Pedersen MB, et al. (2004) Vitamin D insufficiency in Greenlanders on a westernized fare: ethnic differences in calcitropic hormones between Greenlanders and Danes. Calcif Tissue Int 74, 255-263.

46. Yetley EA (2008) Assessing the vitamin D status of the US population. Am J Clin Nutr 88, 558s-564s.

47. Ashwell M, Stone EM, Stolte H, et al. (2010) UK food standards agency workshop report: an investigation of the relative contributions of diet and sunlight to vitamin D status. Br J Nutr 104, 603-611.

48. Islam MZ, Viljakainen HT, Kärkkäinen MU, et al. (2011) Prevalence of vitamin D deficiency and secondary hyperparathyroidism during winter in pre-menopausal Bangladeshi and Somali immigrant and ethnic Finnish women: associations with forearm bone mineral density. Br J Nutr 9, 1-7.

49. Wortsman J, Matsuoka LY, Chen TC, et al. (2000) Decreased bioavailability of vitamin D in obesity. Am J Clin Nutr $\mathbf{7 2}$, 690-693. 